\title{
Falling, Looking, Caring: Red Road as Melodrama
}

\author{
Michael Stewart
}

\begin{abstract}
:
This article examines Red Road as a melodrama and woman's film. It argues that the film is traductively real and melodramatic, and that conceiving the film in melodramatic terms is contrary to the way in which it has been defined in public discourses and academic analysis. Red Road is film melodrama in a number of related ways, via: tropes of narrative and character; a tendency to look back, work through and act out in a melancholy and melodramatic fashion; an emphasis on familialism and redemption; and the nomination of its central character as a woman and mother. Red Road is a maternal text in familiar and complex ways - for example, in the way in which CCTV is inscribed with guardianship and care, and also via Jackie's presentation as a sexual and narrative riddle and other-worldly figure. Jackie's sphinx-like status, the paper argues, connects with Red Road's multiple and twilight qualities, and this is supported by the film's affective elements, including its treatment of the Red Road flats. This treatment helps to engender Red Road's qualities not only of redemption and rebirth, but also of memory and revision.
\end{abstract}

Keywords: Red Road; traductive realism; melodrama; woman's film; CCTV.

\section{Locating Red Road}

Andrea Arnold's first feature, Red Road (2006), won the Jury prize at Cannes. It tells the story of Jackie (Kate Dickie), a CCTV operative in Glasgow who has lost her husband and daughter in a car crash. Jackie spots her family's killer on the CCTV screens at work and begins,

Journal of British Cinema and Television 9.4 (2012): 548-568

DOI: $10.3366 /$ jbctv.2012.0105

(C) Edinburgh University Press

www.eupjournals.com/jbctv 
obsessively, to track him. This leads her to the city's notorious Red Road flats where the killer, Clyde (Tony Curran), lives, as well as to danger, sex and eventual reconciliation.

In assessing and defining Red Road, scholars and reviewers see in it both evidence of certain continuities and something new and potentially radical. For Jonathan Murray, Red Road represents a key stage in the evolution of Scottish cinema, arguing that it is both a 'pronouncedly "European" film' (2007: 86) and a production that contributes to a revised conception of a devolved cinema that feels no obligation to engage with specific questions or representations of the national. David Martin-Jones extends this argument, suggesting that Red Road is a clear example of a Scottish art film which 'conforms to the European art cinema aesthetic' (2009: 225), but in contradistinction to a feature like Young Adam (2003), Red Road also successfully removes recognisable signs of Scotland/Scottishness to become a film that 'literally anyone anywhere can engage with' (ibid.: 229).

For Martin-Jones and Murray, then, Red Road is part of a welcome move away from the idea that any film can or should pursue an imagined national unity. However, in both authors' accounts certain unities still endure. For Martin-Jones, Red Road is new in the way it is more European-universal than it is Scottish. But as Dimitris Eleftheriotis shows, when a film is elevated for its European and universal values, what can also occur is a disavowal of its complex history and politics, or of a distinct identity at all, "because European values are transformed into "universal principles", to be European means to be nothing in particular' (2001: 7). And while MartinJones' definition of Red Road demonstrates an acute awareness of the film's historical and political formation, his underlining of universality and downplaying of markers of Scottishness (or even Glasgow-ness) do prompt questions regarding Red Road's defining characteristics. The answer in part lies in the 'fragile unity' (Eleftheriotis 2001: 9) that endures in Murray's account in which he defines Red Road in familiar European-aesthetic terms, which cohere 'around the important aesthetic movements of European modernity: realism and modernism' (Eleftheriotis 2001: 10). Murray notes that Red Road exhibits a number of the features of the European art film including a remarkable lack of words, an attempt at a visual language able adequately to represent extreme grief, a related compulsion on the part of its characters toward acts of self-destruction, a privileging of a psychological exploration of female interiority and sexuality over narrative coherence and variety of incident, and an attempt to inhabit rather than to explain devastating individual loss (Murray 2007: 86). 
While beginning to capture the aesthetic and thematic qualities of Red Road, whether this description renders it a European art film, as conventionally defined, may be more difficult to judge. Partly this is because there are an increasing number of films being produced which could be described in this way. Moreover as Eleftheria Thanouli argues, definitions of art films (frequently interchangeable in critical discourses with European films) in scholarly literature have tended to cover a problematically broad range of aesthetic styles and production contexts, usually with Hollywood as their significant other (2009: 3). Thanouli invites us to rethink how we define art films, not only because there are problems with the existing classical definitions but also because of recent developments in cinema. One of these developments is in North America and problematises HollywoodEurope dichotomies. This is Thanouli's first 'strand' and comprises the collection of productions termed 'smart film' by Jeffrey Sconce in his influential 2002 Screen essay. Thanouli's other strands are New Iranian Cinema and Dogme 95. Features of all three strands of filmmaking can be found in Red Road, but the film does not fit entirely into any one of them. A line can be drawn between Sconce's 'cold melodramas' and films which focus on abject characters, and the idea of blankness, numbness and abjection reminds us of Murray's description of Red Road-individuals propelled toward self-destruction. But, following Thanouli, I am keen to enquire of what other aesthetic developments Red Road may be a part.

In his assessment of late-twentieth/early twenty-first century European cinema, John Orr argues that disconnection is a common theme. He also suggests that there have been four key developments, which he labels neo-Bazinian realism, traductive realisms, hyperrealisms, and the hypermodern avant-garde (2004: 301). The first two of these are applicable to Red Road. Neo-Bazinian cinema, Orr argues, is characterised by, among other things, location shooting on a small budget, the incorporation of a tangible sense of place into narrative, and the exhibition of 'a nervy, fragmented feel, a plunging into situation that takes its cue ... from the 1980s work of Alan Clark ... [who] used Steadicam ... to generate kinetic energy for a hypermodern age' (ibid.: 304). Meanwhile, traductive realisms, Orr suggests, continue the debt to Bazin but push narrative realism closer to the avant-garde and bring it more fully into abjection, as defined by Julia Kristeva (1982). For Orr, traductively real films are narratives of falling:

It is not the alienation of self into object but the suspension of identity in a world devoid of meaning where abjection is a safeguard, a choice for 
the liminal in the instance of the void. It is the choice to be stranded as protection against the void. The downward flight is a conscious exposure by the abject being to the very dangers from which it seeks to protect itself, and ultimately from death. (2004: 306)

This description captures a number of features of Red Road and its central character. Jackie clearly exists in a void; that which gave her life meaning - her family - has been removed dramatically. She is most obviously stranded in the liminal-falling, submitting to the void-as shown in the scene where we first see her having sex with her colleague Avery (Paul Higgins) in a van in a field somewhere on the outskirts of Glasgow. Her face, pushed up against the passenger window-framed and fragmented in the wing mirror, deathly metallic in shade and accompanied by whistling wind -is an image of joyless abjection.

This is abjection as frozen stasis-as death-and it contrasts sharply with other types of abjection in the film. One of these, following Orr (2004) and Murray (2007), is abjection as movement, compulsion. This is a key way in which theme and form combine in Red Road. The film may be neo-Bazinian because many of its scenes are indeed nervy, fragmented and 'closer on the ground' (Orr 2004: 304), but its traductiveness is expressed via hand-held camera, frequent tracking shots, and the intensity and frequency of close-ups. A key scene in this respect is when Jackie follows Clyde to the Red Road flats for the first time. This indeed is Orr's abjection as exposure to one's most feared dangers. Moreover, Red Road's traductiveness and drama extend beyond the moments when Jackie is led compulsively to Clyde. The film itself has a corporal quality and does all it can, as Murray (2007) notes, to inhabit Jackie's grief. It exhibits abjection, not only as irresistible exposure to danger but also as a form of compulsion and a safeguard - a way in which suffering is expressed via the film's affective and kinetic elements, not least Jackie's body. And while this may not necessarily detract from the European art film or traductive realisms, it does take us toward melodrama.

\section{Red Road and melodrama}

While Hannah McGill suggests that Red Road has elements of classic melodrama (2006: 27), this is not a term generally applied to the film. One historical tradition that certain contemporary melodramas inherit can be articulated in terms of the melodramatic text as a mute text, as a bodily text (Gledhill 1987: 15-18). Moreover, as Sandy FlittermanLewis argues, in film melodrama the suffering of the female character 
provides the 'central articulating crisis', the body of the woman 'the stage across which the melodramatic spectacle is played out' (1994: 5). Women's suffering, then, is communicated via the body as a text, as part of and alongside other affective elements in the film. Indeed for Flitterman-Lewis and others, melodrama achieves its purest form when it is a characteristically mixed mode, combining the theatrical and the cinematic, the poetic and the generic. Moreover, the way in which melodrama continues to mix modes and utilise new and developing forms of cinematic realism is evoked by Robert Burgoyne who, in analysing films from the disaster movie genre, shows the extensive reach both of developing realisms and of melodrama:

They [United 93 and World Trade Center] manifest a disturbing intensity of affect. A sense of adrenalised stasis dominates the tone of each film, a mood compounded by their focus on the profound disconnection ... suffered by the characters. Both films emphasise an inability to communicate, numbing isolation ... As in melodrama, the tensions in the narrative are in effect somatised, displaced into the body of the filmtext. (2008: 150)

Narrative tension in Red Road is in effect doubly somatiseddisplaced on to the body of the film-text via its affective, kinetic and traductive elements, and manifested in Jackie's moving, static, adrenalised, suffering body. And in this respect, while no less traductively real than the European films examined by Orr, the film can also be seen as melodrama. This is indicated by the opening and closing scenes, which also complete a generic rhyme. While McGill (2006) and others emphasise the disciplined, ambiguous, thriller-like character of Red Road's opening, these scenes also introduce us to the affectivity of the lives of ordinary people in an ordinary city and to Jackie's compassion for them. In this respect, her unambiguous, sympathetic expression and what prompts it, the non-diegetic ambient sound and our willingness to read the CCTV images as relatively open, are crucial if we are to comprehend Red Road as melodrama as well as thriller. Moreover, it comes as no surprise that in the closing scenes we are returned to where we started, but this time with greater clarity, light and hope (Williams 1998: 74). We see the same location (Saracen Road, Glasgow) and the same 'ordinary' characters: the dog-walker (John Comerford) with his new dog, and the office cleaner (Carolyn Calder). But here the images are afforded greater purpose - it is the start of the day, rather than night-time as in the opening scenes. Indeed, the way in which these closing scenes turn up the light and 'force ... plenitude of meaning' (Gledhill 1987: 33) makes them conservative as well as remarkable. 
We begin a new day with new possibilities signified via lighting, colour, sound and an early-morning sky and an early-morning city scene.

As if this wasn't confirmation enough, in its final moments the scene shifts registers and gears again, cutting from an objective, medium shot of Jackie walking south down Saracen Road to (ostensibly the same scene and moment in time) an image that is in long shot, much brighter (the sun is shining) and from the point of view of a CCTV camera. Brightly lit and grainy, the latter shot is both highly constructed, pushing its artificiality to the limit, and confident in its status as real. It is indexical and also hyper-omniscient, now stripped entirely of its agent, Jackie. The shot seems fantastical, but it also suggests that this is no longer a fantasy: Jackie has crossed over. If her CCTV world constituted a melodramatic fantasy of sorts - a world close enough but far away, of mini-dramas, death and disappointment, but above all humanity and connectedness - then Red Road's ending indicates that she has left this safeguard behind and is ready again for the real world.

The film here squeezes as much humanity as it can from a CCTV image and as much utopia as is possible from an unglamorous Glasgow street. Melodrama begins and ends, as Linda Williams argues, in spaces of innocence, utopia and nostalgia (1998: 65). It may be pushing it to suggest evidence of nostalgia in these closing moments, but nostalgia is plain in the domestic scene that precedes these shots. Photographs of her family surround Jackie when she returns at last to her in-laws' home and it is a photo of a cherished memory that provides her with a location for her daughter and husband's ashes-Loch Lomond, one of the family's favourite places.

This scene is also melodramatic in other ways; most obviously, it is the completion of Jackie's psychoanalytic journey. Following Burgoyne, a useful distinction can be made between Red Road as a traumatic text that works through, and one that acts out (2008: 150). The domestic scene with Brenda (Anne Kidd) and Alfred (Andy Armour) is, in Freud's terms, a working through: 'Psychical work which allows the subject to accept certain repressed elements and to free himself from the grip of mechanisms of repetition' (Laplanche and Pontalis 1988: 488). Indeed, much of Jackie's journey is both looking back and working through, often simultaneously. Static shots of her face looking back - at the wedding reception and when she walks home from it - are good examples of this, both nostalgic and pathetic, trying to re-order the past and revise the present.

The former is a particularly poignant moment. Jackie attends the wedding of her sister-in-law, Jo (Cora Bissett), who is delighted but surprised she has come. An elderly man in the church doorway seems 
more surprised still to see Jackie. We cut from the church to the hotel reception, with the party in full swing. Jackie sits, smiling, clapping, vicariously enjoying the dancing. The elderly woman beside her, Aunt Kath (Annie Bain), tells her to 'get up and dance'; Jackie protests she can't dance and Aunt Kath replies: 'Bollocks! You danced all night at your own wedding'. This confirms a family history as well as the strength and humour of Aunt Kath's character, while also keeping the enigma of Jackie's past alive. After more warm banter, Jackie leaves the dancing to go to fetch a trifle for Aunt Kath, and in the corridor encounters the elderly man from the church doorway. He is carrying a beer and some food and is unsteady on his feet. Jackie looks trapped and, unable to meet the man's eye, glances back at the dancing. The man (at the end of this scene we learn that he is Alfred, Jackie's father-in-law) comments on Jackie's appearance and tells her that he preferred her hair when it was long. This leads him to a reflection on the past: the first time he met Jackie, and the last time he saw 'him' (we might guess here that this refers to his son, Jackie's absent husband). Alfred's words, unlike those of Aunt Kath, lack warmth. They sound as much an accusation as a reflection. He stares at Jackie who continues to look away and glance back at the party. In an attempt to fill the painful silence, Jackie offers to get Alfred a trifle too, but he brushes past, saying that his beer will get cold. She makes a choked and too-late appeal, 'Alfred ...', and is left isolated and shot from behind in the corridor. In a medium close-up shot at shoulder height, she turns and looks back again at the party. Aunt Kath and the other dancers are held and framed by a small, rectangular pane of glass (the upper panel of an internal door). At this moment, Jackie and the film seem to want to freeze and box-away the past: a family life left behind, tradition, and an older generation. But the sequence-the shot-reverse-shot - is more complex than this; first, because Aunt Kath, for all her familiar miserablism ('we'll be bloody dead soon'), is in full swing, dancing, waving and laughing - her movement counterpointing Jackie's stillness; and secondly because Jackie's held, framed look is not only wistful and backward. In its final moments it is unsure and searching, as if she sees something for the first time in this festive scene. We then cut abruptly to Jackie outside, walking quickly away from the wedding reception.

These working-through moments recur frequently in Red Road and stand against more melodramatically wilful sequences of acting out:

Action in which the subject, in the grip of his unconscious wishes and phantasies, relives these in the present with a sensation of immediacy 
which is heightened by his refusal to recognise their source and their repetitive character ... Acting out often takes the form of aggressive behaviour directed either at the self or at others. (Laplanche and Pontalis 1988: 4)

The most obvious and excessive acting-out sequence begins with Jackie entering the Broomfield Tavern and, following a graphic sexual encounter with Clyde that she engineers in order to entrap him with an accusation of rape, ends with her standing numb, 'successful' but still traumatised, in a police station shower. This is John Orr's traductiveness as compulsive submission, but also goes beyond that. It is an excessive masquerade and performance, or acting out as 'a melancholy possession of the subject by the past' (Burgoyne 2008: 150). In the bar scene, Clyde and Jackie act out noir in a setting closer to a western. And Jackie's noirish fatalism is given its final performative flourish in Clyde's bathroom, where she becomes more crudely and calculatingly dangerous than at any point in the film: acting out in front of the mirror the final parts of her plan, lit in shadow and steelycold blue-grey. In the bedroom she acts out her fantasy of rape by Clyde which, in Burgoyne's terms, is a melancholic indulgence, and history and blame as highly circumscribed, as how they 'ought' to be.

What strikes me about these excessive moments is that they are also an acting out of Red Road as it 'ought' to be. They are a brief delivery of the thriller promise, considerably amplified in the film's publicity and reviews. Red Road's sentimental, pathetic, working-through elements form the greater part of the narrative, and perhaps, following Doane, commit the bigger rape. Sentiment, argues Doane, can be violent, pathos 'a kind of textual rape' (1991: 304). If a viewer is captivated at all by what turns out to be pathetic, they feel complicit, violated, more masochistic or feminine than they might care to admit. The film has manipulated and cheated them: 'From this perspective, it is not at all surprising that the maternal melodrama tends to produce the uncomfortable feeling that someone has been had' (ibid.: 304).

This helps to explain some reviewers' surprise and disappointment at Red Road's failure to deliver its lean, disciplined promise, as well as the fact that it successfully resists terms like melodrama and the woman's film. Moreover, even in these sensationally melodramatic acting-out scenes there are strong elements of sentiment and familialism, and exposition as working through-for example, Clyde stepping in as a better father-figure to stop Stevie (Martin Compston) attacking someone whom we subsequently discover is his biological father; Stevie turning pathetically to his new symbolic family-April 
(Natalie Press) and Clyde-as he falls asleep by the fire; and Clyde revealing his hopes for (as well as the existence of) his biological daughter.

The domestic scene with Brenda, Jackie and Alfred is also a familiar melodramatic moment of motherly sympathy and return. A crying Jackie is engulfed, swept up into the bosom of Brenda, 'a maternal figure ... of forgiveness and understanding' (Burgoyne 1994: 227). Jackie here is a child and is dispatched into the world by her mother (in-law). And to some extent it could be argued that this is Jackie's role in the closing scenes of Red Road: I've watched over you, my (soap opera-CCTV) children, and now you are ready to start afresh. You are independent of me now, and I must find my own way too.

This moment continues rather than counters the preceding scene, which is not only about working through and heavy-handed exposition but also a direct incident of Jackie mothering a character toward a familial destiny. What makes Jackie soften at last, and give Clyde a measure of credibility and morality, is his daughter, and the fact he is a father, a father who, it has been shown, cares. 'Your daughter was looking for you', she feels duty-bound to tell Clyde. And, not for the first time, she tells a rejected lover to go back to his family.

In melodramatic terms (Gledhill 1987: 33), Clyde's morality now could not be more legible: the crash was an accident and he has paid for his mistake. It is clear he wants to go straight and, most of all, to love and be loved. Jackie's morality has been little troubled and what this scene further reveals and confirms is that the deep pain that she feels is the pain of a mother. Just prior to her daughter's death, we learn, she had let her mothering function slip. Her last words to Sorcha were not of love and care, as they 'should' have been; they were of exasperation and rejection: 'I told her to get out my sight'.

This, the film suggests, is a key measure of the pathos that we should feel for Jackie, because her status as a mother extends not only to Sorcha, Clyde and the characters (dog-walker, office cleaner) of the CCTV mini-dramas, but to all the figures she observes on her monitors. Consequently, when she lets her duty of care slip and a girl is stabbed whilst she is pre-occupied with Clyde's movements, the guilt that Jackie feels is first and foremost the guilt of a mother.

\section{Red Road and the woman's film}

While critics like Martin-Jones (2009) and Sillars and Macdonald (2008) have described Red Road in womanly terms, they do not go as far as to call it a woman's film. Yet the 'woman's melodrama', 
as Barbara Creed argues, 'is a moral tale' (in Cook 1991: 251)-a tale that works its way through transgression, desire, temporary happiness, opposition, separation, atonement and capitulation, and features mutually contradictory states of possession and loss, desire and frustration, power and impotence, fulfilment and lack (ibid.: 251). These complexities are ultimately contained by patriarchal ideology, so that femininity in the woman's melodrama is shown typically as caring, compassionate, sensitive and, above all else, maternal (ibid.: 251). In these terms, then, Red Road can be seen as a woman's film, and Jackie as 'an icon of maternal suffering' (Flitterman-Lewis 1994: 12). Whether the film's complexities are contained ultimately by patriarchal ideology is debatable, but what is clear is that, very early in Red Road, Jackie is nominated (Williams 1998: 72; Rothman 2004: 87) as a woman and mother - though this is not a straightforward process.

Jackie is a mixed emblem and maximised type (Gledhill 1991). She is assuredly (if at the risk of crude physiognomy) a paradigmatic choice-Kate Dickie is both able to 'do' androgyny and hawkish in looks, recalling John Orr's characterisation of the abject's 'downward flight' (2004: 306) as well as Lisa Mullen's description of Jackie's CCTV bank as an eyrie (2006: 78). It also takes us to the very opening moments of Red Road: the first objects we see, disembodied, softly lit and in medium close-up, are Jackie's hands. One reading of this shot is that these are preening, predatory hands-and the shadowy setting, ambiguous soundscape, and especially the opening titles would seem to support this. But as already noted, we then move immediately to the face behind the hands, and see it is a caring and compassionate face. Thus, the setting and music become less sinister, less leanly narrative, and more warmly affective. Then, in a familiar gesture - the rubbingin of hand cream-Jackie's hands are also rendered less predatory and more caring: caring hands are careworn hands.

Thus, the hands, the setting and Jackie are actually mixed signs of danger and care. In this respect, Jackie's CCTV bank is both a home and a trap - in Orr's terms, it does indeed cocoon and protect Jackie. It is a warmly lit, shadowy den and point of return, giving Red Road its spidery narrative form. It is where Jackie returns after foraying out and, given the film's public framing as revenge thriller and the metaphor of CCTV as a web, it is not a huge leap of imagination to conceive of Jackie as some kind of mythical spider-woman. Animal metaphors, it would seem, spring quite readily to mind in discussions of Red Road; for example, Sillars and Macdonald note Clyde's link to a scavenging and medieval fox (2008: 196). But Jackie is the key figure regarding the malleability and potency of (motherly, animal, maximised) typing. 
The film also manifests more or less obvious parallels between Jackie and Clyde. Most suggestively, by the conclusion of Red Road, both Clyde and Jackie have completed spells in prison - Jackie's CCTV bank can be conceived of as her prison as well as her home. It is a womb, a cave and a trap-and an expression of maternal doubling. In some theories of cinematic regression, as Lucy Fischer shows, Plato's cave functions not only as a prison but as a womb-a place of infantile comfort and moving shadows (1996: 25). This is also applicable to Jackie, who sits numb, passive, but not altogether unhappy in front of flickering images that she wants to read as human. Moreover, there is a forceful coming together in Red Road of Jackie's warm, shadowy den and the frequent extreme close-ups of her caring face: 'The face in the close-up is, in essence, the mother's face, the breast, the primal unity of infancy' (Eberwein in Fischer 1996: 26). This is one key way in which Red Road is marked out or nominated not only as a woman's film but as a complex maternal melodrama.

Typically, perhaps, the complexity resides at once in the film and in Jackie: she is the riddle, the snare, the obstacle. Following Teresa de Lauretis, Jackie's passivity in her womb-like den might make her an easy obstacle to overcome: a princess waiting to be won (in Fischer 1996: 25). Red Road nods to this myth-Clyde rescues Jackie from a violent setting, throws her over his shoulder, takes her back to his own liminal den and makes love to her - but it is no more than a nod. Jackie is in very few ways a princess. Moreover, it is arguable that she both embodies the 'maternal constellation' (Burgoyne 1994: 232) of angel, demon and whore, and subverts it. Like the princess, Jackie only toys with the figure of the whore, briefly invoking an uncomfortable rape fantasy en route to ensnaring Clyde in, precisely, a rape fantasy of revenge.

More interesting is the way in which Jackie combines angel and demon without being unequivocally or conventionally angelic or demonic. At this point, it is worth considering Red Road's soundtrack, or more accurately its soundscape. Sillars and Macdonald have noted the special character of this, linking it to the film's thriller status, the urban uncanny and Glasgow's post-industrial landscape (2008: 195). This reference to the ghostly and uncanny deserves expansion because little of Red Road's soundscape is in fact 'dissonant clanks and wheezes ... trains shunting, machines clanging' (ibid.: 195). The majority of the spare but frequently present non-diegetic soundscape is indeed rather ghostly and uncanny - ethereal or, in melodramatic terms, numinous. Connotatively it is open, or at least multiple. Sometimes it functions fairly straightforwardly for the purposes of 
existentialism-poetry-nostalgia: there are what feel like obligatory shots of empty bags and urban detritus climbing and falling, floating in the wind; birds on a dawn sky; Jackie standing at a run-down shop front, alone, lit by the morning sun. And also it is used-problematically-at points to make the Red Road flats sinister and dangerous.

But frequently this numinous soundscape is quite pointedly and powerfully attached to Jackie. There are two noteworthy moments in this respect. First, when Jackie says goodbye to her sister-in-law at the wedding reception and we cut to the former walking home slowly at night along a busy street. Both Jackie and the film are in observational, contemplative mode here, and the sequence begins with 'natural' diegetic sound: sounds of the city at night, joined by light, colour and movement. The framing (medium-close at shoulder height and in profile) and slow, steady movement make Jackie at once regal and ethereal. She is stillness in life, a living image. She then sees and approaches two of her CGTV 'children': the sick dog and its owner. At this point, diegetic sounds are joined by non-diegetic ones or, rather, are joined by sounds whose status as diegetic or non-diegetic is unclear. It is a soft lone voice and a call to prayer, and its diegetic/non-diegetic status is less important than its strong attachment to Jackie and her contemplative and compassionate face-the face here of a mother and a seer, an other-worldly guardian figure.

The second moment is briefer and more angelic still. When Avery drops Jackie off after their first (for us) fortnightly field outing, she is left standing alone in medium-long shot outside at a bus station at sunset, numb and lifeless after joyless sex. The sound again, initially, is natural and diegetic. But for a moment, Jackie's still, dark outline is held-the sinking sun breaks through this outline just below her face so that its rays are clear, but Jackie is not obscured and the image is joined, appropriately it seems, by one brief but extended ghostly nondiegetic note. Jackie is still, in profile, hands clasped in front of her, and bows her head slightly as the moment ends. The ghostly, numinous soundscape, then, frequently would seem to suggest that Jackie is not just suspended and falling, she is also not entirely of this world.

For de Lauretis in her theorising of the maternal, the more effective narrative and oedipal obstacle is the sphinx (in Fischer 1996: 25), and just as angel and demon combine under their definition as guardian spirits, so is the sphinx, like Jackie, the guardian of the city: watching over it and allowing, or not, human traffic to pass. When Clyde tries to look at Jackie in Red Road's latter, powerful bar scene, he fails to recognise her. And he does not recognise that he is trying to do something that he did not dare to do before (in court): look at her. 
In this way Jackie is a sphinx, a dangerous riddle which Clyde tries to solve: 'Look at me'. In residual (Victorian) conceptions of woman, the line between the divine and the demonic is thin (Auerbach 1982). And in the potent figure of Jackie the lines between danger, predation and care, frequently, are fine. This is clear when she first visits the flat lived in by Clyde, Stevie and April. The exchange of words between Jackie and April in the kitchen, when both characters first enter the flat, is awkward and ambiguous, and it is as easy to read this exchange as surveillance and policing as it is as sisterly/motherly interest. Elsewhere, though, Jackie's compassion and sense of female solidarity are clear: at the wedding reception, in the exchanges between Jackie and her sister-in-law and Jackie and an elderly relative; at the Red Road flat again, when Jackie attempts to protect April from Stevie's insensitive prank; and in the way in which Jackie looks at and responds to the office cleaner's highs and lows. All of these scenes are variously about caring and compassion, but they are also about particular ways of looking.

\section{Jackie, CCTV and the Red Road flats}

To state the obvious, Jackie's look is frequently mediated via CCTV. If she embodies danger and care, the same is true of the CCTV: the apparatus is inscribed both with dangerous drama and human, even maternal, care. If Jackie is a maximised type, then, accordingly, Jackie is CCTV: they are one and the same thing, one and the same maternal, demonic body. This is evident from the very beginning of Red Road, when the film's affective elements - especially Jackie's face-suggest that the opening CCTV images of Glasgow are both sympathetic and dangerous. Part of the conceit is that such images are culturally loaded; they signify crime and deviance and that a dramatic reality bite - that is, the violent expression of crime and deviance-is never far away. Yet Red Road both depends on and reproduces this assumption while simultaneously seeking to overturn it.

Early in the film, the meaning of CCTV images is not just doubled but unclear. When Clyde first flickers into grainy view, Jackie initially fails to recognise him-or, rather, she locates him in the abstract as male-predator-criminal. Then she thinks she is seeing things, which is when the film makes CCTV images magically real and turns Clyde into a fox. The film's invitation to drama here is strong, and it is made via both the CCTV images and Jackie. Both are shocked, fearful, incredulous, unclear but simultaneously conclusive (quickly confirmed by a call to the solicitor). Jackie's world is upside down and she is 
persecuted and scared-both the protagonist and the CCTV images are paranoid.

The CCTV apparatus is here being put to the service of the woman's film. Jackie's problem is a 'lack of knowledge and understanding of the forces which control her destiny'. (Cook 1991: 253). She finds herself in a world that must investigate. Her perspective is paranoid. Cook's definition of the woman's film is supported by Modleski who, in her analysis of Rear Window, argues that suspense, narrative and paranoia work together in films whose focus is women (2005: 78). The scene in which Jackie first enters Clyde's flat is a good example of this combination. At this moment Jackie is somatised, over-determined, apparently compelled. Her need to gatecrash Clyde and Stevie's party is urgent, but it is not clear why. The camera is typically close behind her head, 'nervy and closer on the ground', as she tails Stevie and April into the block of flats and then chases them to catch the lift. The tension in the lift is palpable, but Jackie cannot resist staring at Stevie and April-close associates of the object of her investigation. This recklessness increases the danger of her being unmasked, especially by Stevie who, it is clear, has a short fuse. The film plays on this by having Stevie demand: 'Who invited you?', and then remarking that 'He's a dirty cunt!' when Jackie says that it was Clyde, rationalising that it is not at all unusual that Clyde should have invited a woman that Stevie hasn't met, given his relations with many women. In the small flat, the camera remains closely focused on Jackie's face, her eyes nervous and compulsive to the point of 'wildness'. She clings desperately to and swigs frequently from her bottle of VK. Her exchange with April in the cramped, flatly lit kitchen is a study in mis-communication and, as noted earlier, uncomfortably mixes sisterly concern and compulsive investigation. Jackie drifts toward the living room, dimly lit and full of partygoers and loud music, and spots her apparent quarry, Clyde. She then moves back out into the narrow hall, tightly framed in medium-close from behind, so that our knowledge of her snooping can quickly become that of another character - so that the shot can move seamlessly from objective to subjective, direct point-of-view. Jackie opens one ajar door and scans a bedroom; she then moves to try another door and is indeed caught, predictably perhaps, by Stevie. The tension peaks and is again quickly deflated when Stevie assumes that Jackie is looking for the toilet and tells her where it is. Jackie then moves back into the living room and stares intently at Clyde. At this point, the film shifts in two ways: from Jackie as nervy, compulsive investigator to Jackie mesmerised or caught in a trance; and from being aligned closely with Jackie to a very close but more objective 
study of Clyde and Jackie's encounter. Jackie and Clyde are shot at shoulder height in both close-up and extreme close-up. The lighting is dim, gauzy-red. The music is loud and stops when Clyde asks if they've met. When Jackie says she's seen him in the café, it is clear that he has no memory of this. The music is loud again but slow, and Jackie seems now to have lost control. They embrace and the encounter is played for abandonment, intimacy and hazy eroticism. We move between extreme close-ups of both characters' faces and Clyde's hands moving down, squeezing Jackie's rear. The direct shot from Jackie's point of view loses focus; they seem to be on the brink of losing themselves in each other completely when Jackie suddenly breaks free and says she has to go home, leaving Clyde bemused. We rush with Jackie out of the flat, the camera close and unsteady, the lighting flat and unforgiving again. She enters the lift and is clearly disoriented and distressed, leaning on the walls of the lift as if it is a ship about to sink, before convulsing and vomiting on the floor.

If we feel suspense during this scene, then to some extent this depends on whether we care about Jackie or think of her as an 'unlikable snooper' (Modleski 2005: 78). More broadly, Modleski argues that this type of suspense is a defining feature of narrative cinema and can be theorised as a profoundly feminine and masochistic fantasy (ibid.: 78). Narrative, then, is a suspension of the rational and ordinary, a submission and abandonment, a 'licensed and benign paranoia' (Scholes in Modleski 2005: 78). In this respect, Jackie's abjection can be argued to be both a defining feature of narrative cinema and an expression of a developing traductive realism. Whether the abject is more frequently a woman as well as feminine may be debatable, but what is clear in this 'snooping' scene is that the drama and Jackie are indeed one. She is the nervous, unsure, paranoid, somatic text, 'a riddle to be read for its symptoms' (Cook 1991: 254).

This is underlined in various ways, so that Jackie is an explicitly feminised and sexualised riddle. This is figured early on in Red Road by Avery's slightly bemused post-coital refrain that he 'can never tell' whether Jackie has reached orgasm or not, and the transparent falseness of Jackie's reassurance that on this occasion she did, 'earlier'. Further, Richard Dyer argues that frequently when the question of a woman's sexuality is implied, women characters' body images in film become "tougher, harder and more "masculine" (2004: 53). This would seem to fit Jackie's lean, angular, sculpted frame, as well as Alfred's clear disappointment at the wedding reception that, in his judgement, Jackie has changed to become less feminine. 
This riddle and this paranoia are also in some ways how we can understand the CCTV apparatus. The grainy, unclear images work effectively in Red Road because they hold out a promise, but of what we are left unsure. They invite a scrutiny that is denied both by their characteristic lack of clarity and the ambiguity of Jackie's 'condition' or quest. But this does not prevent Red Road using CCTV images latterly and melodramatically to force meaning (Gledhill 1987: 33). Frequently in melodrama, as Linda Williams argues, spectacle and high drama work to drive the film to narrative resolution while simultaneously displacing and helping us magically to forget preceding moral and ideological complexities (1998: 75). Stevie's dramatic and violent break-in to Jackie's house and his attack on her in bed may be a key scene in this respect. A quick rifle through Jackie's purse is enough to persuade Stevie that she is telling the truth and is justified in her actions. This is light in terms of narrative plausibility, but it is not the first appearance of Jackie's purse-a vulgar Freudian object, a riddle to be read for its symptoms (Modleski, 2005: 74)-and thus this scene serves to underline both Clyde's essential goodness as well as Jackie's motivations for ensnaring him. But perhaps equally important in guiding Jackie toward redemption and rebirth - in producing a typically melodramatic change of heart (Gledhill 1987: 17)-is one of Red Road's final CCTV spectacles. This is the moment that Jackie stares intently at her own television screen (another tape brought home) and witnesses an episode that places a key piece into the familial puzzle, helping her to reinvest hope in the future: when Bronwyn, Clyde's daughter (Jessica Angus), goes in search of her father, for the first time, we assume, at the Red Road flats. If this is a low-key spectacle, it is also a potent coming together of Jackie and CCTV's maternal function.

Here the CCTV is benign and the Red Road flats perform a mainly narrative function. This is in sharp contrast to the first time that the flats appear on Jackie's screens at work and in the sequence when she first visits the flats in person. At these moments the flats are looming, hulking and monstrous in the way that they are framed (from below and filling the screen), lit (in shadow), and accompanied by the film's characteristic soundscape; in short, they are coded as ominous, dangerous. If the flats provide a placeless backdrop (Martin-Jones 2009: 198) for the examination of universal questions, they are also a paradigmatic choice, loaded with mostly negative meaning which Red Road does little to unpack.

But like the CCTV, the flats are multiple in their manifestations in Red Road. Two of the most noteworthy shots of them occur when Jackie leaves late in the afternoon, having missed Clyde, had a nervy 
encounter with Stevie and April, and lost (had stolen) her purse. These images are less about abjection, danger and a reduced understanding of the flats and the past, and more about transience, fantasy and memory; they are Sillars and Macdonald's (2008) ghostly and uncanny. The first shot lasts only four seconds and occurs between Jackie leaving the flat and getting on the bus to go home. In terms of narrative and continuity editing, it signals an ellipsis, the short passage of time that it takes Jackie to get from the flats to the bus stop: the flat scene is lit for the late dusk of late afternoon, but when Jackie steps on to the bus it is dark. Yet this sequence lasts approximately six seconds of screen time.

The brief, dusky image of the flats is remarkable: the framing is ambiguous and adds to the tension between the indexical and the surreal. It is a dirty, occluded, abstract shot without any obvious anchor and seems ghostly, showing the top section (approximately thirteen of 31 floors) of one block of flats which appears to be partially in the clouds, a dusky twilight shot of greys, blues and pinks. The sounds are also dirty and fragmented. If the shot is held for four seconds, then the first second is accompanied by Stevie bellowing to April to come here-a bleed from the preceding flat scene. Viewers might then anticipate the rumble of the bus engine. But there is no engine in the shot's remaining three seconds, indeed barely any sound at all. Just audible is the wind, eternal companion (as Stevie so forcibly showed) to this high, remaindered place, and this sound is then joined, via bridge sequences, with a near-wind, ghostly tone from the film's non-diegetic soundscape.

The second shot of the flats occurs after Jackie has taken her seat on the bus. This time it is a broadly focalised objective shot-looking back, past Jackie, behind her and through the rear window of the bus. This in some ways is yet another looming shot of the flats as sinister and dangerous, but it is also as close as Red Road dares to get to the flats as the urban-enchanted. The soundscape is the same signature ghostly uncanny, but this time its meaning, and the meaning of the flats, is opened by soft, night-time lighting-orange-glowing street lamps-and less severe framing of the flats as they recede from view.

These two shots are what Robert Burgoyne calls memory traces, in which memory 'clings to places just as history clings to events' (2008: 163). The Red Road flats in this respect are magnified objects which 'evoke the strange silence' (ibid.: 161) and are endowed with a symbolic aura which 'typically draws on the symbolism of death and rebirth' (ibid.: 164). Jackie's memories represent neither the past nor the 
future, but an uncertain historical present - the liminal, or in Andreas Huyssen's terms, the twilight: 'An image which might make the past strange again' (Caughie 2000: 225). Most suggestively, Burgoyne employs St Augustine's metaphor of the memory cavern - the interior life as 'memory's huge cavern' (2008: 165) with its mysteries and secrets, and which, argues Burgoyne, may be made visible and affective and shared in the collective experience of cinema. This takes us back to Jackie's cave and expands it because, by these terms, all of Red Road is a cavernous re-working of the past. The flats are not only a regressive bogeyman, a heart of darkness, Jackie's holiday of repair. They, along with the CCTV apparatus, are technologies of memory and reclamation. They become liminal zones, where Jackie is both the border guard and the border crosser. The border crosser, notes Anna Ball, is a key figure in postcolonial feminist theory and in some women's films - especially those films which mix in complex ways the lines of gender, sexuality and nation (2008: 20-1).

However, Red Road's engagement with questions of the national is not so much less explicit than in the films examined by Ball, as nonexistent. In his analysis of recent Scottish female friendship films, Martin-Jones argues that while recognisably Scottish sets can inform the examination of women's lives and relationships in post-industrial society, the focus on the latter tends to come at the expense of an engagement with questions of Scotland and Scottishness (something which, in a sense, Ball suggests, remains an aspiration for Palestinian film). It would be easy to read the traditional-national-patriarchal as the cost of Jackie's renewal in Red Road. Clyde, a primitive, romantic, whittler of wood, laments what might have been if only he too had had the chance of love. And for all his unravelling of the riddle of Jackie-who, during their final meeting, still barely meets his eye-on the hill, at the edge of the city, he is nonetheless sent back to whence he came: his new prison, the demonic flats. The flats, Clyde and the past have served their purpose, and now Jackie can turn her back on them and the shadow that they cast, and march south toward the sun and the city.

\section{Conclusion}

However, ultimately Red Road's vision and agency are not as singular as this. The film's focus is Jackie, who has indeed crossed over and is no longer falling. But her future is uncertain and she remains in suspension - neither as unflinchingly hopeful as the film's final images, nor as impossibly regretful as its finishing song. This uncertainty is 
both welcome and complicated. In some ways Red Road represents a missed opportunity; as Chris Petit argues: 'Surveillance in art and cinema remains a conceit' (2010: 43). Questions of the technology's failure, its impact on local government and on conceptions of public and private space, Petit argues, are generally ignored in recent film and television featuring CCTV. Nevertheless, his fascination for CCTV images remains, and he notes 'their combination of theatricality and suspense, and their logging of low-key, perimeter landscapes beyond the usual reach of cinema and television' (ibid.: 43). And CCTV in Red Road is successful in that it does capture these qualities, reminding us of the dangerous places that the technology surrounds, monitors, fears and forgets, and to some extent inviting us to re-remember them, but differently. But the CCTV apparatus in Red Road, as I have suggested, is perhaps most interesting in the way that it attaches itself to Jackie as one maternal body. In this respect, the very final CCTV shot in the film should be seen as indicative rather than disappointing. What it points to is the continued renewal of the figure of woman, malleable, 'marvellous and terrifying' (Rothman 2004: 95), not only in the Victorian imagination, as Auerbach (1982) indicates, but, as Rothman suggests, in contemporary film and culture. And what it also points to is 'characters on the move' (Street 2009: 150) and a Scottish cinema in transition.

The uncertainty in Red Road is assuredly historical, just as the uncanny, for all its in-between-ness, is also always historical, as Charlotte Brunsdon reminds us (2007: 50). British cinema's strong sense of place would be impossible without the ontological link between nominal setting and actual location' (Nowell-Smith in Brunsdon 2007: 216). And as Peter Hutchings notes, in recent times these settings and locations have frequently been anxious and apocalyptic 'scenes of urban abandonment' (in Brunsdon 2007: 47). Moreover, Brunsdon suggests that the melancholia evident in cinema studies in recent times is not only about technology, time and perceived loss, but is also concerned with place; and that this overlaps with economic and social change and 'the role of cinema in relation to vanishing buildings and landmarks' (2007: 211).

As well as providing a setting and backdrop, the Red Road flats are a landmark - of history and of Glasgow. Red Road both disavows this and is keenly aware of it. The flats are no less an actor than Kate Dickie; no less a stage across which the melancholic and melodramatic spectacle is played out. This shifting outline is the backdrop against which Jackie's journey is set. And David Martin-Jones is right that it informs this journey-sometimes in predictable and even disappointing ways, 
but also in ways that are hesitant, uncanny and almost magical, and therefore not altogether devoid of hope.

\section{References}

Auerbach, N. (1982), Woman and the Demon: The Life of a Victorian Myth, Cambridge, MA: Harvard University Press.

Ball, A. (2008), 'Between a postcolonial nation and fantasies of the feminine: the contested visions of Palestinian cinema', Camera Obscura, 23: 3, pp. 1-33.

Brunsdon, C. (2007), London in Cinema: The Cinematic City Since 1945, London: BFI.

Burgoyne, R. (1994), 'National identity, gender identity, and the "rescue fantasy" in Born on the Fourth of July', Screen, 35: 3, pp. 211-34.

Burgoyne, R. (2008), The Hollywood Historical Film, Oxford: Blackwell.

Caughie, J. (2000), Television Drama: Realism, Modernism, and British Culture, Oxford: Oxford University Press.

Cook, P. (1991), 'Melodrama and the women's picture', in M. Landy (ed.), Imitations of Life: A Reader on Film and Television Melodrama, Detroit, MI: Wayne State University Press, pp. 248-62.

Doane, M. (1991), 'The moving image: pathos and the maternal', in M. Landy (ed.), Imitations of Life: A Reader on Film and Television Melodrama, Detroit, MI: Wayne State University Press, pp. 283-306.

Dyer, R. (2004, 2nd edn), Heavenly Bodies: Film Stars and Society, London: Routledge.

Eleftheriotis, D. (2001), Popular Cinemas of Europe: Studies of Texts, Contexts and Frameworks, London: Continuum.

Fischer, L. (1996), Cinematernity: Film, Motherhood, Genre, Princeton, NJ: Princeton University Press.

Flitterman-Lewis, S. (1994), 'The blossom and the bole: narrative and visual spectacle in early film melodrama', Cinema Journal, 33: 3, pp. 3-15.

Gledhill, C. (1987), 'The melodramatic field: an investigation', in C. Gledhill (ed.), Home is Where the Heart is: Studies in Melodrama and the Woman's Film, London: BFI, pp. 5-39.

Gledhill, C. (1991), 'Signs of melodrama', in C. Gledhill (ed.), Stardom: Industry of Desire, London: Routledge, pp. 207-29.

Kristeva, J. (1982), Powers of Horror: An Essay on Abjection, New York: Columbia University Press.

Laplanche, J. and Pontalis, J.-B. (1988), The Language of Psychoanalysis, London: Karnac. Martin-Jones, D. (2009), Scotland: Global Cinema-Genres, Modes and Identities, Edinburgh: Edinburgh University Press.

McGill, H. (2006), 'Red Road', Sight and Sound, November, pp. 27-8.

Modelski, T. (2005, 2nd edn), The Women Who Knew Too Much: Hitchcock and Feminist Theory, London: Routledge.

Mullen, L. (2006), 'Red Road', Sight and Sound, November, p. 78.

Murray, J. (2007), 'Scotland', in M. Hjort and D. Petrie (eds), The Cinema of Small Nations, Edinburgh: Edinburgh University Press, pp. 76-92.

Orr, J. (2004), 'New directions in European cinema', in E. Ezra (ed.), European Cinema, Oxford: Oxford University Press, pp. 299-317.

Petit, C. (2010), 'Watching you watching me', New Statesman, 24 May, pp. 42-4.

Rothman, W. (2004, 2nd edn), The 'I' of the Camera: Essays in Film Criticism, History and Aesthetics, Cambridge: Cambridge University Press. 


\section{Michael Stewart}

Sconce, J. (2002), 'Irony, nihilism and the new American "smart” film', Screen, 43: 4, pp. 349-69.

Sillars, J. and Macdonald, M. (2008), 'Gender, spaces, changes: emergent identities in a Scotland in transition', in N. Blain and D. Hutchison (eds), The Media in Scotland, Edinburgh: Edinburgh University Press, pp. 183-98.

Street, S. (2009), 'New Scottish cinema as trans-national cinema', in J. Murray, F. Farley and R. Stoneman (eds), Scottish Cinema Now, Newcastle: Cambridge Scholars, pp. $139-52$.

Thanouli, E. (2009), “'Art cinema” narration: breaking down a wayward paradigm', Scope: An Online Journal of Film and TV Studies, June, available at http://www.scope. nottingham.ac.uk/article.php?issue $=14 \&$ \&id $=1136($ accessed 10 October 2011).

Williams, L. (1998), 'Melodrama revised', in N. Browne (ed.), Refiguring American Film Genres: History and Theory, Berkeley: University of California Press, pp. 42-88.

Michael Stewart is the film and media programme leader at Queen Margaret University, Edinburgh. He has published articles on film and television melodrama in various journals, including Cinema Journal, Scope and Critical Studies in Television. $\mathrm{He}$ is currently working on an edited collection of essays on contemporary film and television melodrama. 